\title{
The Position of the Czechoslovak Economy in the Global Economy in the Years 1945 - 1989
}

\author{
Marian Lebiedzik \\ Silesian University in Opava \\ School of Business Administration in Karvina \\ Karvina, Czech Republic \\ lebiedzik@opf.slu.cz
}

\begin{abstract}
This article focuses on the situation of the economy of Czechoslovakia in the global economy from the period after World War II up to 1989. Economic development in this period was significantly influenced by the political events that took place in Czechoslovakia in 1948, when it became part of the Eastern Bloc and a system of central planning was introduced into the economy. Despite the many problems that a centrally planned economy creates such as the considerable degree of closure of the economy to foreign competition, the lack of selected goods on the market, the persistence of an inadequate market structure, Czechoslovakia in the late 1980s ranked among the 30 most developed economies in the world and the most developed in the Eastern Bloc.
\end{abstract}

Keywords-Czechoslovakia; global economy; structure of foreign trade; economic level

\section{INTRODUCTION}

Prior to World War II Czechoslovakia was an industrialagrarian market economy. At this time it was certainly not one of the most developed countries, which were Great Britain and Switzerland. However, it could be classified as a moderately developed country alongside such countries as Austria, Finland and Norway.

A major turning point in the development of the Czechoslovak economy was World War II and the associated occupation of Czechoslovakia by Nazi Germany. The end of the war in 1945 was associated not only with the defeat of fascism, but also with the new political system of Europe and the world. Original assumptions about postwar cooperation between the East and West were not confirmed, their relationship gradually deteriorated and in 1946 the Cold War was declared. The liberation of Czechoslovakia for the most part by the Soviet Army and a certain complex about the Munich Agreement (resulting from not very good pre-war experiences with the political orientation of Czechoslovakia towards Great Britain and France) ushered in both the political and economic directions of Czechoslovakia for the next 45 years to come.

The aim of this paper is to evaluate the position of the Czechoslovak economy in the global economy at a time when it was centrally managed, using basic macroeconomic indicators which are commonly used for the purposes of analysis and comparison of this type. The state of the economy in this period had a significant influence on its further development after 1989 to the present day, where it is now a normally functioning market economy.

\section{DEVELOPMENT BETWEEN 1945 AND 1948}

An important change for post-war Czechoslovakia was that within the framework of the agreement on the post-war organization of the world it lost part of its territory, SubCarpathian Rus, and the half a million people that lived in it at the time, to the Soviet Union. The agreement also permitted Czechoslovakia to expel the German population predominantly living in the border area from its territory. This expulsion concerned about 2.3 million Sudeten Germans and logically effected the economic development of the Czechoslovak border region for a long period of time after. These facts led to a "reduction" in the size of the Czechoslovak economy compared to the interwar period.

Despite the effects of the above factors, Czechoslovakia tried to find its own way of connecting its economy to the global economy between 1945 and 1948. It was assumed that it would be involved in trade with countries both in the East and the West. Czechoslovakia actively participated in the work of all the major world economic organizations of the time, including the International Monetary Fund and the International Bank for Reconstruction and Development. At the same time policy-makers were aware of the need to modernize the structure of the Czechoslovak economy and redirect it towards new modern industries such as the electrical industry, which was hardly represented in Czechoslovakia prior to World War II. Since such a fundamental change in the structure of the economy required significant financial resources, which the Czechoslovak economy decimated by war lacked, efforts were made to take advantage of assistance offered by developed countries (mainly the USA) and participate in the so-called Marshall Plan which offered funds to help rebuild European economies after the war.

All these efforts failed due to a coup in February 1948, when Czechoslovakia began on the path of constructing socialism. Czechoslovakia rejected the aforementioned Marshall Plan and in 1949 created the Council for Mutual Economic Assistance (CMEA) together with other countries of the Eastern Bloc. Czechoslovakia was an industrial country in the framework of the CMEA and was expected to help in the industrialization of the other members of the group whose 
economies were largely agrarian-oriented. In 1951, Czechoslovakia finally assumed the Soviet Union's centrally planned model of economic management.

\section{DEVELOPMENT BETWEEN 1948 AND 1989}

Membership in the CMEA and a clear focus on the construction of socialism greatly simplified the international trade relations of the Czechoslovak economy. Over time, as indicated in Table 1, there was a significant territorial reorientation of foreign trade from developed countries to countries with a central economy. It is clear from the table that during these 40 years there are characteristic periods where there is a radical decline in the foreign trade of Czechoslovakia with economically developed countries on the one hand, and an increase on the other hand. The most significant decrease can be observed between the years 1948 and 1960, where there was a strict implementation of the central control of the economy following the example of the Soviet Union. With the political and economic reforms in the late 1960s, which was a response to disappointing economic developments in the first half of this decade and the associated economic and technological lagging behind the world, there was a certain strengthening of the position of developed market economies in the structure of the foreign trade of Czechoslovakia. The failure to promote political and economic reforms, which culminated in the occupation of Czechoslovakia by troops of the Warsaw Pact in 1968 and subsequent normalization, resulted mainly in the 1980s in a further significant increase in trade with centrally planned economies at the expense of developed economies.

TABLE I. TERITORIAL STRUCTURE OF THE FOREIGN TRADE OF CZECHOSLOVAKIA (IN \%)

\begin{tabular}{|c|c|c|}
\hline Year & $\begin{array}{c}\text { Economically developed } \\
\text { countries }\end{array}$ & Centrally planned economies \\
\hline 1948 & 60,3 & 39,7 \\
\hline 1950 & 44,4 & 55,6 \\
\hline 1960 & 28,2 & 71,8 \\
\hline 1970 & 34,7 & 65,3 \\
\hline 1980 & 35,8 & 64,2 \\
\hline 1988 & 29,1 & 70,9 \\
\hline
\end{tabular}

Source: Nykryn, J. Zahraniční obchod. I. vydání. Praha: Svoboda, 1998.

In terms of commodity structure Czechoslovakia became the exclusive supplier of engineering products to all of the other countries of the Eastern Bloc, as shown in Table 2. The necessary raw materials were provided mainly from the Soviet Union.
TABLE II. COMMODITY STRUCTURE OF THE FOREIGN TRADE OF CZECHOSLOVAKIA (IN \%)

\begin{tabular}{|c|c|c|c|c|}
\hline Commodity & $\begin{array}{c}\text { Import } \\
\mathbf{1 9 4 8}\end{array}$ & $\begin{array}{c}\text { Export } \\
\mathbf{1 9 4 8}\end{array}$ & $\begin{array}{c}\text { Import } \\
\mathbf{1 9 6 0}\end{array}$ & $\begin{array}{c}\text { Export } \\
\mathbf{1 9 6 0}\end{array}$ \\
\hline Foodstuffs & 34,9 & 5,5 & 23,0 & 5,3 \\
\hline $\begin{array}{c}\text { Raw } \\
\text { materials and } \\
\text { intermediates }\end{array}$ & 55,2 & 40,9 & 53,1 & 29,6 \\
\hline Products & 9,9 & 53,6 & 23,9 & 65,1 \\
\hline
\end{tabular}

Source: Nykryn, J. Zahraniční obchod. I. vydání. Praha: Svoboda, 1998.

In terms of the economic level measured by GDP/capita it is possible to see a gradual deterioration of the country's position in the global economy after 1948 compared to before World War II, when the Czechoslovak economy was among the 18 most developed countries in the world. Although Czechoslovakia occupied a leading position in the world for some indicators (production of coal and steel), the production often referred to did not end with the final product, but again, with intermediates. The share of consumption in the production of the product in Czechoslovakia in the 1970s was over 50\%, while in comparable developed economies it was only around $35-40 \%$.

The International Comparison Project (ICP), which has been published by the United Nations in regular five-year intervals since the early 1970s, ranked Czechoslovakia 28th in the world in terms of the level of gross domestic product produced per capita in 1980, whereas in 1987 Czechoslovakia raked better in 25th place. The GDP/capita converted using purchasing power parity exchange rate in the latter mentioned year was 7745 USD. The top rated country Kuwait reached 15 598 USD for this indicator, and second place was occupied by Norway (13 213 USD) and in third place was the United States (13 093 USD).

Based on the above mentioned data, it is possible to generally regard the economy of Czechoslovakia at the end of the 1980s as a middle-industrialized country. Somewhat less favorable, however, was the fact that over time, as documented in Table 3, the difference between the economic levels of Czechoslovakia and most other Western European market economies widened. The reasons for this can be seen in the inadequate structure of the economy and the demands for raw material and energy intensity of production associated with obsolete capital equipment and low levels of scientific and technological progress. The consequence of this is the resulting low competitiveness of our goods on world markets and the resulting low level of participation in the international division of labor, which amounted to around one third of the level in Austria. 
TABLE III.

GDP/ CAPITA (PPP) IN CSSR AND SELECTED EUROPEAN COUNTRIES (IN USD)

\begin{tabular}{|c|c|c|c|c|c|c|}
\hline Country & 1970 & Difference 1970 & 1980 & Difference 1980 & 1987 & Difference 1987 \\
\hline CSSR & 5732 & $0,0 \%$ & 7002 & $0,0 \%$ & 7745 & $0,0 \%$ \\
\hline Austria & 5843 & $1,9 \%$ & 8230 & $17,5 \%$ & 9182 & $18,6 \%$ \\
\hline Switzerland & 9164 & $59,9 \%$ & 10013 & $43,0 \%$ & 10942 & $41,3 \%$ \\
\hline Belgium & 6750 & $17,8 \%$ & 9087 & $29,8 \%$ & 9085 & $17,3 \%$ \\
\hline Netherlands & 6915 & $20,6 \%$ & 9036 & $29,0 \%$ & 9369 & $21,0 \%$ \\
\hline Finland & 6186 & $7,9 \%$ & 8393 & $19,9 \%$ & 9748 & $25,9 \%$ \\
\hline Denmark & 7776 & $35,7 \%$ & 9598 & $37,1 \%$ & 11094 & $43,2 \%$ \\
\hline
\end{tabular}

One of the causes of the economic lag of Czechoslovakia in this period was the inappropriate sectoral structure of the economy. In 1985, the primary sector contributed about $12 \%$ to the total gross domestic product, the secondary sector $52.9 \%$ and the tertiary sector contributed only $35.1 \%$ to GDP. From this it is clear that our economy in this period showed a traditional structure of ISA, the same as during the First Republic. From this perspective, despite the relatively high value of GDP/capita, Czechoslovakia cannot be ranked among the economically advanced countries, which at that time had a modern economic structure, where the service sector prevailed. One of the reasons why similar shifts in the economic structure did not occur in Czechoslovakia as in Western economies, was the implementation of the centrally planned economy, which in the case of Czechoslovakia was based on rapid industrialization with a focus primarily on heavy industry as a sector that had the task of ensuring armament requirements during the Cold War.

\section{CONCLUSION}

During the period of the centrally planned economy the position of Czechoslovakia in the global economy was somewhat worse compared to the period before World War II. At the end of the 1980s it was ranked between 25th and 28th place in the world's most advanced economies. The biggest problem of the Czechoslovak economy, however, was its outdated economic structure which had a prevailing one-sided focus on heavy industry i.e. highly energy and resource intensive products with low added value. This reflected on the commodity structure of foreign trade and its territorial orientation towards states of the Eastern Bloc or developing countries.

Fundamental political changes took place in most countries of the Eastern Bloc after 1989. This was accompanied by economic reforms and transformation of the economies of these countries from a centrally planned economy to a market
Source: VÚROM Study, 1989., own calculation

based economy. These changes were often accompanied by a sharp decline in the economic levels and an undermining of the position in the countries concerned in the global economy, and Czechoslovakia was no exception in this regard. In the case of Czechoslovakia the process was accompanied by another important event which was the separation of the Czech and Slovak Republics. Another important milestone in terms of the future direction of both countries was in 2004 when they joined the European Union.

\section{REFERENCES}

[1] S. Cameron, "Stručné ekonomické dějiny světa," 1. vydání, Praha: Victoria publishing, 1996.

[2] E. Cihelková a kol. "Světová ekonomika, nové jevy a perspektivy," Praha: C.H. Beck, 2001.

[3] J. Faltus, V. Průcha, "Všeobecné hospodářské dějiny 19. a 20. století,". 1. vyd. Praha: VŠE, 1996.

[4] Kolektiv autorů, "Studie VÚROM,” 1989.

[5] M. Lebiedzik, "Makroekonomická pozice České republiky v rámci Evropské unie (ekonomická výkonnost a konvergence)," Karviná:SU OPF, 2006.

[6] B.R. Mitchell, "European Historical Statistics 1750-1993," Lomdon: Macmillan, 1998.

[7] J. Nykryn, “Zahraniční obchod,” I. vydání. Praha: Svoboda, 1998. 